\title{
THE MUSEUM OF ФУТБОЛЬЬНЫЙ
} COSMONAUTICS

\section{РЕКОРД МУЗЕЯ}
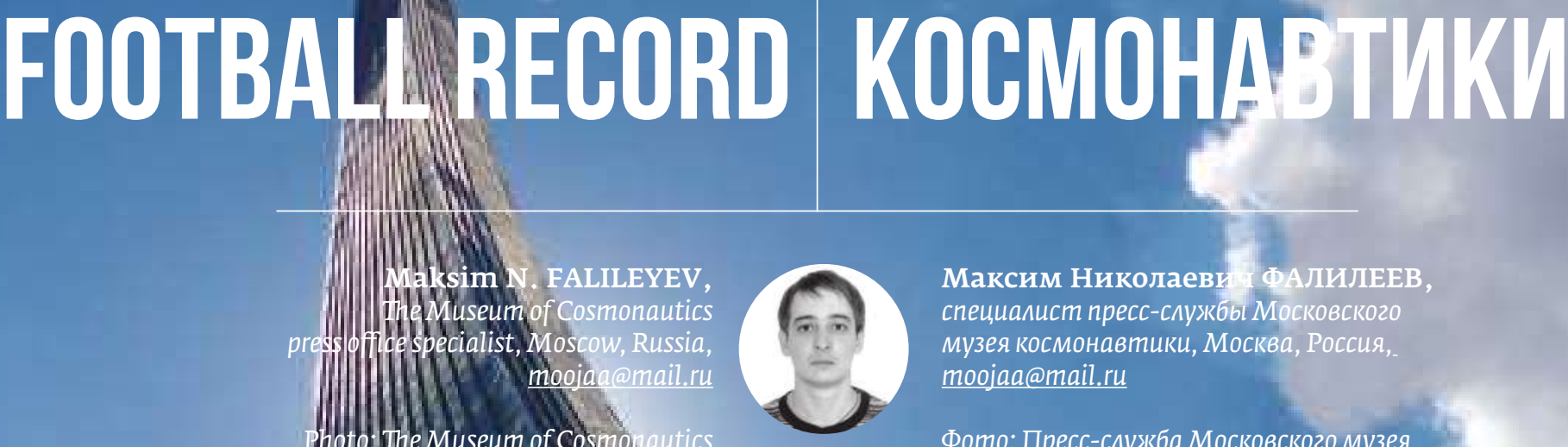

Макскм Нкколаевц фАЛИЛЕЕВ, специалист пресс-службы Московского музея космонавтики, Москва, Россия, moojaa@mail.ru

Фото: Пресс-служба Московского музея космонавтики
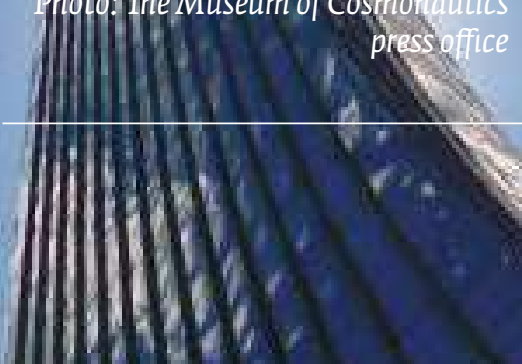

ABSTRACT I From the first days of FIFA World Cup a new point of attraction for the fans from all over the world has flashed on the Moscow map. In June-July the Museum of Cosmonautics headed the list of the city's most visitable cultural establishments. During the 31 day of World Cup 2018 the Museum of Cosmonautics hosted 17175 tourists.

Keywords: the Museum of Cosmonautics, FIFA World Cup, foreign fans, flash mob "Space pass»
АінотАция I с первых дней чемпионата мира по футболу на карте Москвы вспыхнула новая точка притяжения болельщиков со всего мира: Музей космонавтики в июне-июле возглавил список самых посещаемых культурных учреждений города. За 31 день чемпионата Музей космонавтики принял 17175 туристов.

Ключевые слова: Московский музей космонавтики, чемпионат мира по футболу, иностранные болельщики, фолешімб «Космический пас» 


\section{СПУТНИК КАК СИМВОЛ ЧЕМПИОНАТА МИРА}

Главный символ освоения космоса - первый искусственный спутник Земли - оказался на телезаставке матчей Кубка мира, а арена в Самаре получила имя "Космос» - в честь местного предприятия «Прогресс», на котором создаются ракеты. Еще один символический факт: официальный мяч турнира побывал на борту Международной космической станции, а на Землю вернулся за считанные часы до начала официальной церемонии открытия.

Наконец, самые громкие успехи отечественной космонавтики и футбола практически совпадают по времени - десятилетие между 1956 и 1966 годом. О наших достижениях того времени в космосе известно всем, напомним успехи сборной СССР по футболу: золото Олимпийских игр в 1956 году, первый Кубок Европы в 1960 году и финал Кубка Европы в 1964 году, а также полуфинал чемпионата мира в 1966 году. Главные наши звезды тех лет - Юрий Гагарин и Лев Яшин - до сих пор самые узнаваемые и известные русские космонавт и футболист.

Любопытно, что и финальный аккорд советской космической программы - запуск легендарного "Бурана» в ноябре 1988 года - также совпал с последними нашими футбольными достижениями. Именно в 1988 году сборная СССР по футболу снова выиграла Олимпийские игры, а на чемпионате Европы заняла второе место, только в финале уступив сборной Нидерландов.

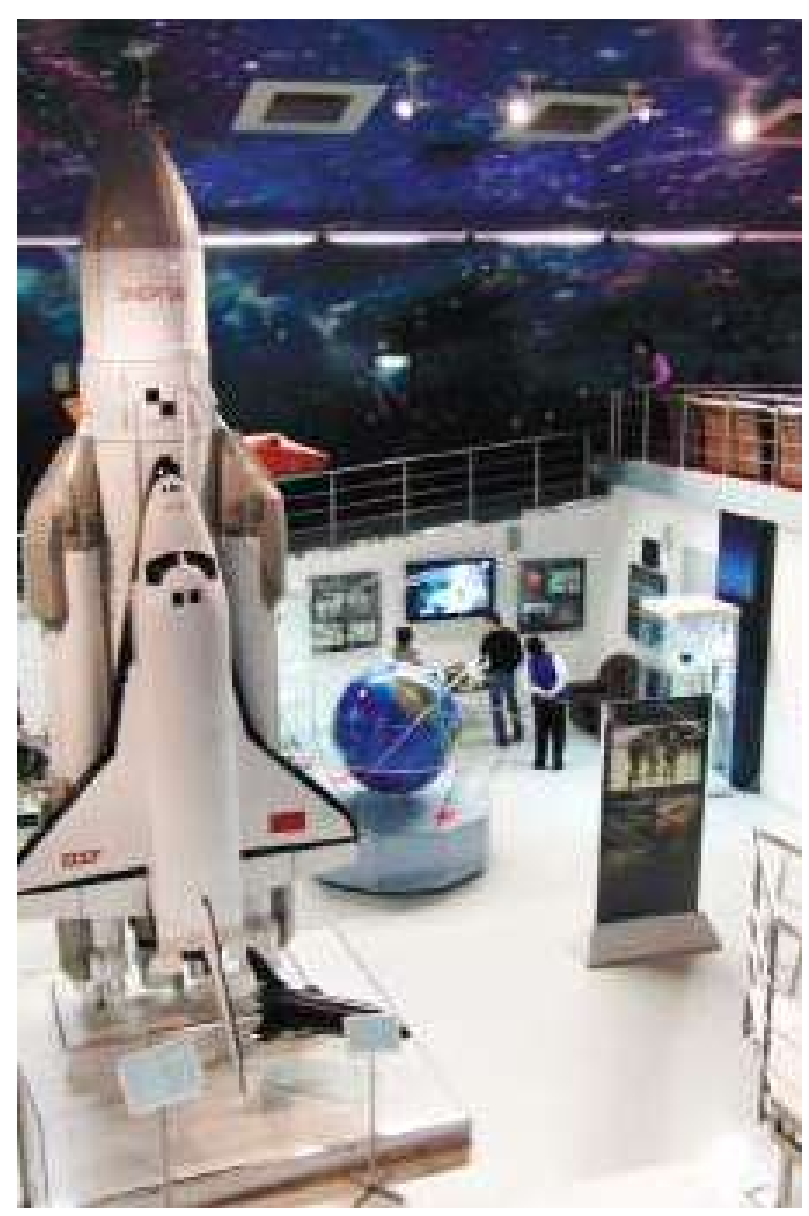

Гонсало Бонадео, спортивный радио- и

тележурналист, автор многих книг о футболе, ведущий собственной программы на Общественном телевидении Аргентины

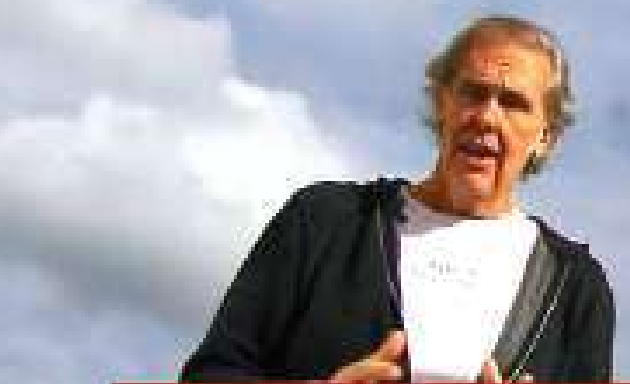

EL MUSEOAEROESPACLAL Y EL EMBLEMA RUSO: EL COSMONAUTA
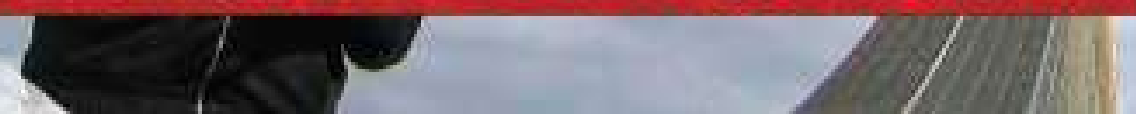


\section{ОТКУДА В ДАЛЕКИХ АМЕРИКАХ ЗНАЮТ O PУССКOM KOCMOCE?}

Говорит Вячеслав Климентов, заместитель директора музея по научной работе: «Наш музей очень посещаемый, но до начала чемпионата мира по футболу такого наплыва иностранных гостей не было. К чемпионату мы начали готовиться за год. Фокус этой подготовки был на работе со СМИ. Любой журналист, который приезжал к нам, был желанным гостем. И нам кажется, что именно эта подготовка помогла привлечь такое огромное количество болельщиков из разных стран мира».

На вопрос: «Откуда в далеких Америках знают о русском космосе?» - болельщики отвечали: «Перед чемпионатом мира в Латинской Америке выходило большое количество телепрограмм, посвященных России и городам турнира. Во многих из них нам очень рекомендовали посетить этот музей».

И действительно, телеканалы Аргентины, Мексики, Колумбии, Бразилии и других стран континента, словно опровергая штампы о вечном латиноамериканском карнавале и южной необязательности, подарившей миру крылатое выражение "маньяна» («любое время между завтра и никогда»), еще в прошлом году отправили в Россию съемочные группы. Рекламой нашего космоса прониклись даже те, чьи сборные на чемпионат не отобрались - в музее встречались туристы из Сальвадора и Гондураса, стран не самых зажиточных даже по меркам Центральной Америки.

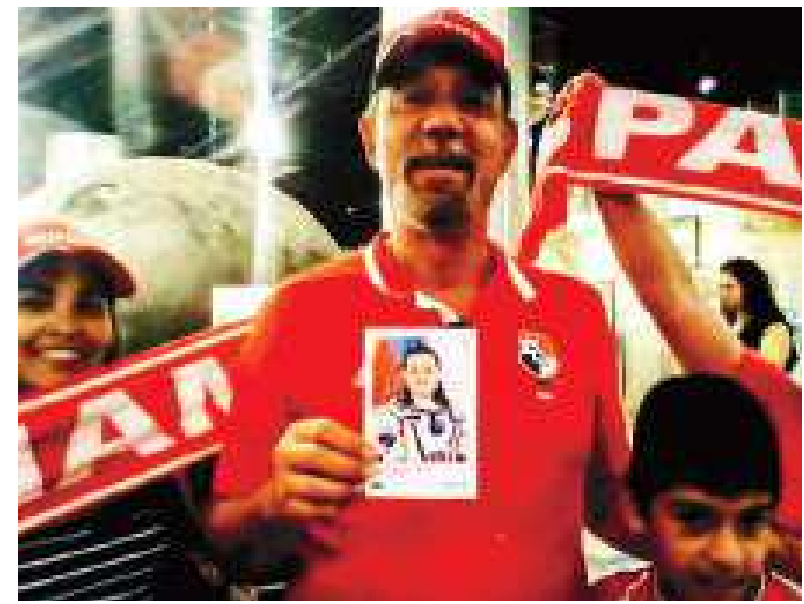

Марсело Пенья из Панамы, участник флешмоба Музея космонавтики «Космический пас»

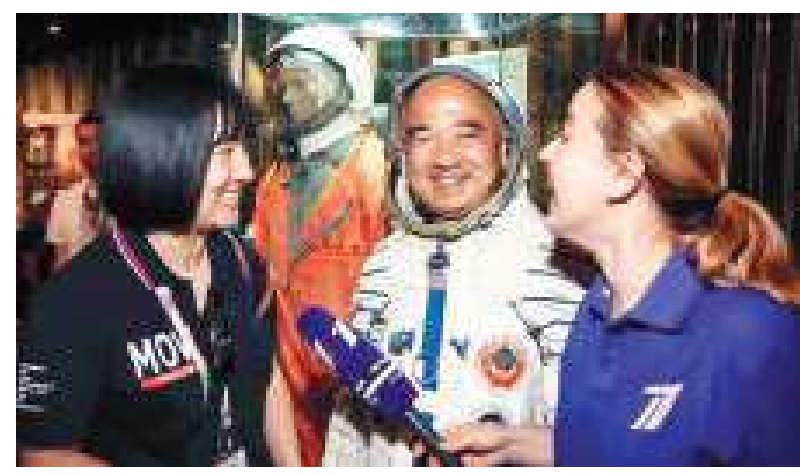

Фрагмент репортажка Первого канала об иностранных болельщиках в Музее космонавтики

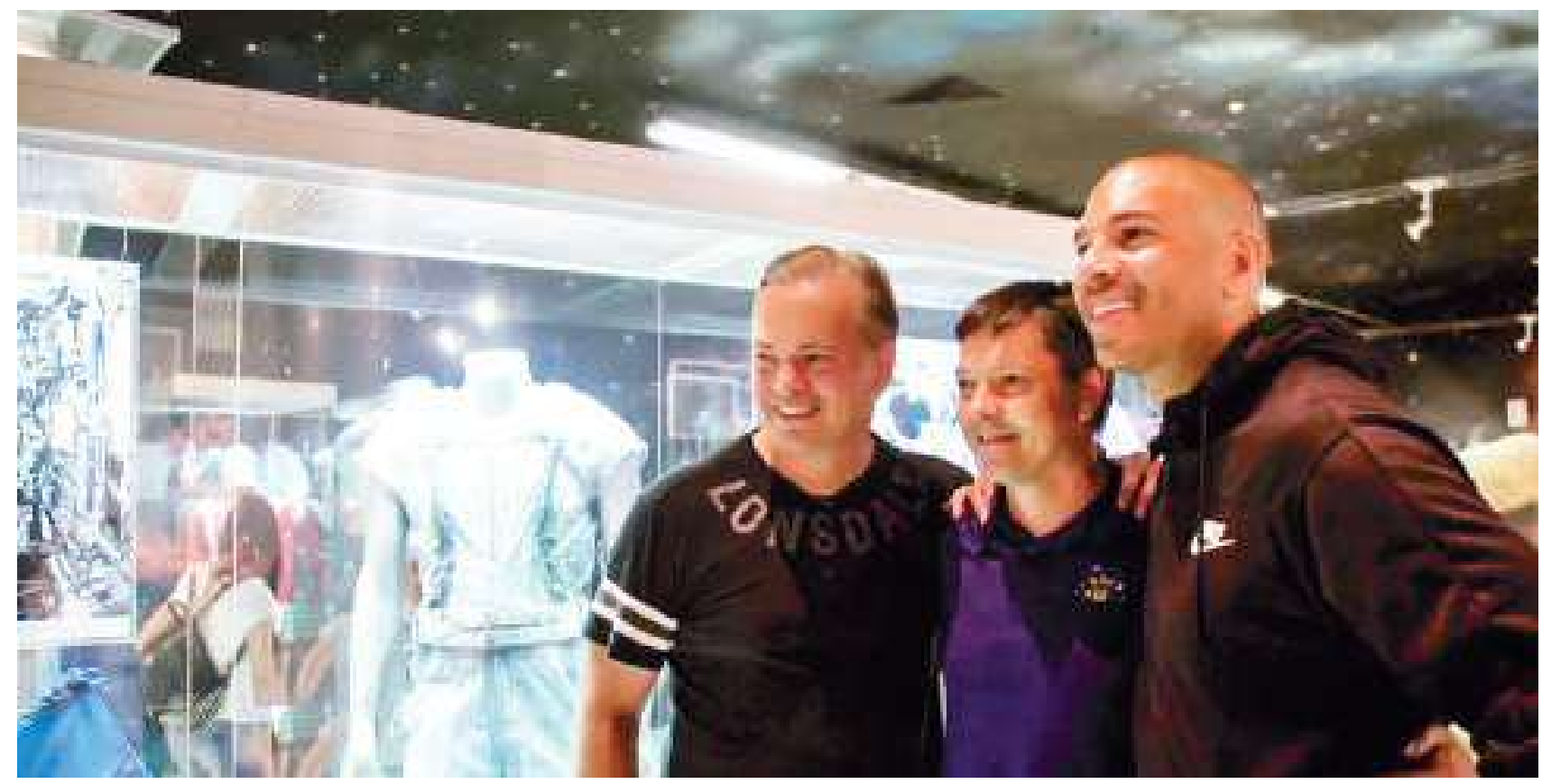




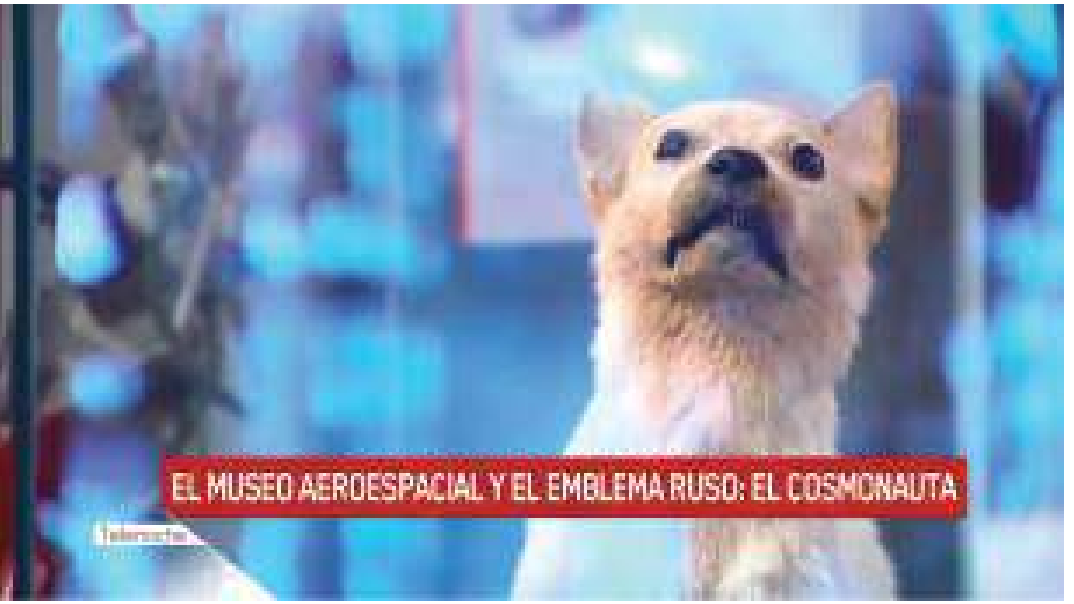

Космическая собака Белка - героиня сюжетов аргентинского (и не только) телевидения
Экскурсовод Музея космонавтики Анастасия Куприна делится впечатлениями: «Самые популярные экспонаты у иностранных болельщиков - все те, что являются оригинальными или очень похожи на настоящие. Космический корабль и чучела Белки и Стрелки, макет базового блока станции «Мир», макет лунохода, скабандры первых космонавтов... Иностранцы очень ценят возможность узнать чтото новое о России, прикоснуться к истории. Поэтому, наверное, самый большой интерес вызвали те экспонаты, которые можно потрогать руками к метеоритам, например, всегда была очередь».

\section{"РУССКАЯ РИКОТТА॥ - СУВЕНИР ИЗ КОСМОСА}

Латинская Америка удивила не только количеством фанатов, прибывших в Россию, но и ответственностью, с которой гости из этой части света подошли к поездке в нашу страну. Поразили перуанцы, которых в Россию приехало почти 50 тысяч. Специально к чемпионату мира болельщики этой страны изготовили футболки «Мы - Перу. Мы вернулись» (на чемпионатах мира сборная этой страны не участвовала с 1982 года) - на русском языке!

Вячеслав Климентов: «Музей отмечен на картах Google как знаковое и рекомендованное для посещения место Москвы. Когда я спрашивал болельщиков из Испании, Аргентины, Франции, Перу, Португалии: “Откуда вы узнали о нашем музее?» - они с большим удовольствием доставали из своих рюкзаков путеводители на разных языках и показывали мне в них наш Музей космонавтики».

Фанатский ажиотаж в музее космонавтики не объяснить лишь солидными скидками на входные билеты, ведь по тому же «Паспорту болельщика" можно было попасть за полцены в любой из множества московских музеев. Космическая тематика - до сих пор одна из самых популярных на Западе из тех, что в массовом сознании связаны с Россией.

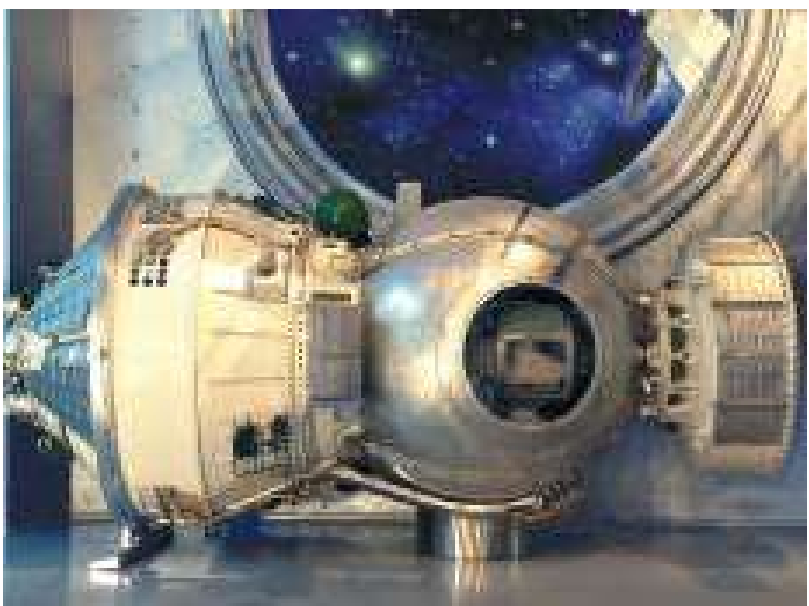

Почти 20 тысяч иностранцев, побывавших в музее, словно заново открыли для себя достижения советской эпохи и узнали о том, что Россия - по-прежнему космическая держава. Хотя в основном, конечно, вопросы иностранных поклонников футбола были весьма наивны, напоминали детские: «Как космонавты спят или едят? Где в космосе туалет? Где сейчас находится спутник?» и так далее.

Самый же популярный подарок, который болельщики увозят с собой из музея - тюбик космической еды, как правило, творога. Необычный русский "деликатес» уже зарекомендовал себя на Международной космической станции, где давно стал лакомством для американских и европейских астронавтов. Теперь же Russian ricotta, как называют творог латиноамериканские болельщики, распробовали и на другом конце земного шара. 


\section{«ПОЕХАЛИ!॥ ОТ ЗВЕЗДЫ ФУТБОЛА}

Космос соединяет в себе истории подвига и новейшие технологии - и, конечно, объединяет людей. Пресс-служба Музея космонавтики организовала флешмоб "Космический пас»: по всему миру разлетелись 122 открытки с портретами наших героев-покорителей космоса. Гости музея, болельщики из десятков стран, произносили имена советских и российских космонавтов - и делали "космический пас" на свою родину: друзья и родственники тех, кто принял участие в флешмобе, должны повторить имена и фамилии космонавтов и отправить музею свой "космический пас» в ответ. Всего в флешмобе приняли участие 244 болельщика из 46 стран. Имена советских и российских космонавтов прилетели со всех материков и даже из космоса - друг друга на орбите представили космонавты Олег Артемьев и Сергей Прокопьев!

После полуфиналов в музей приехал Стэн Коллимор, знаменитый в прошлом нападающий «Ливерпуля» и «Астон Виллы», сейчас - ведущий телекомпании Russia Today и собственного шоу на чемпионате мира. Сборная его страны остановилась в шаге от главного матча турнира, однако расстроенным Стэнли не выглядел, скорее напротив. Экскурсию по музею для гостя провел летчик-космонавт Олег Кононенко, который уже совсем скоро начнет подготовку в составе 58-й экспедиции на МКС. В книге по- четных гостей музея Стэн Коллимор оставил вместе с обязательным автографом знаменитое «Поехали!», латинскими буквами.

Вся эта история об огромной популярности музея стала приятным сюрпризом - как и, например, спонтанно возникшая фан-зона на Никольской улице или сенсационные результаты сборной Хорватии. То есть ожидать чего-то подобного было можно и нужно, однако реальность оказалась круче любых прогнозов. О «нашествии" футбольных болельщиков на Музей космонавтики рассказали и главные телеканалы страны - фанатов в окружении ракет и спутников снимали Первый, "Звезда", "Россия" и другие. И когда казалось, что музеи вообще и Музей космонавтики в частности - история не про чемпионат мира по футболу, взгляд со стороны показал - нам есть чем восхищаться самим и чем удивлять заморских гостей.

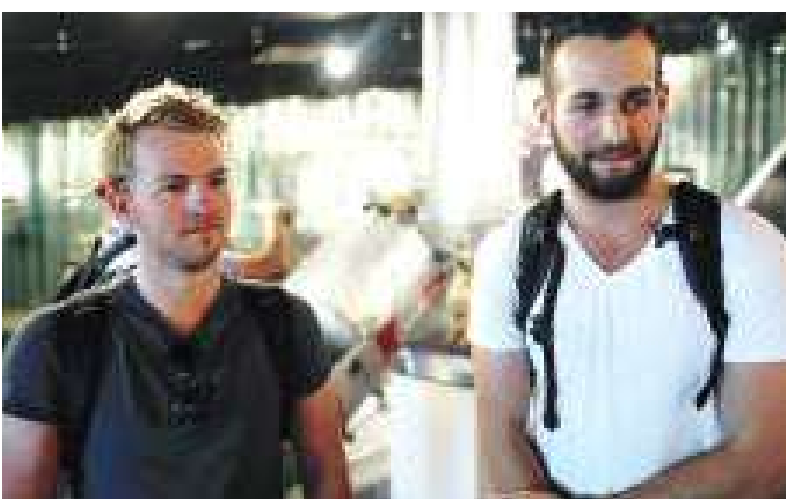

Престон и Джек, болельщики из США

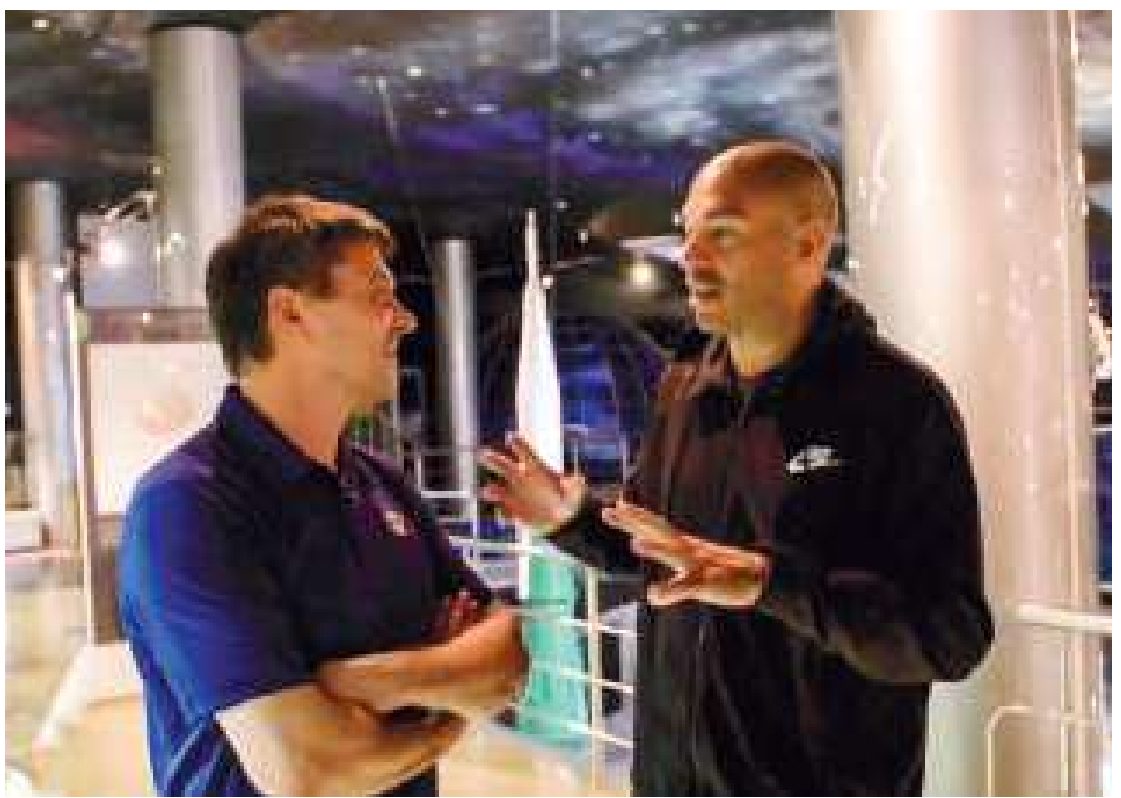

Олег Кононенко, летчик-космонавт, Герой России, и Стэн Коллимор, экс-футтболист «Ливерпуля», ведущий Russia Today - на экскурсии в Музее космонавтики
Вячеслав Климентов продолжает: «Мы были рады кажсдому болельщику. Администраторы и волонтеры рассказывали, куда им еще сходить, какой кухни отведать, раздавали карты культурных мест Москвы, подготовленные Мосгортуром. Не только болельщики заряжались космосом и вдохновением, но и мы заряжались оптимизмом и хорошим настроением от них. Специально для наших гостей мы ввели дополнительные сборные экскурсии на английском языке - группы собирались четыре раза в день. И даже проводили прямые трансляции матчей чемпионата. И мы знаем, что некоторые болельщики шли специально смотреть матч к нам в музей, а не в бан-зону, совмещая просмотр футбола с экскурсией». 


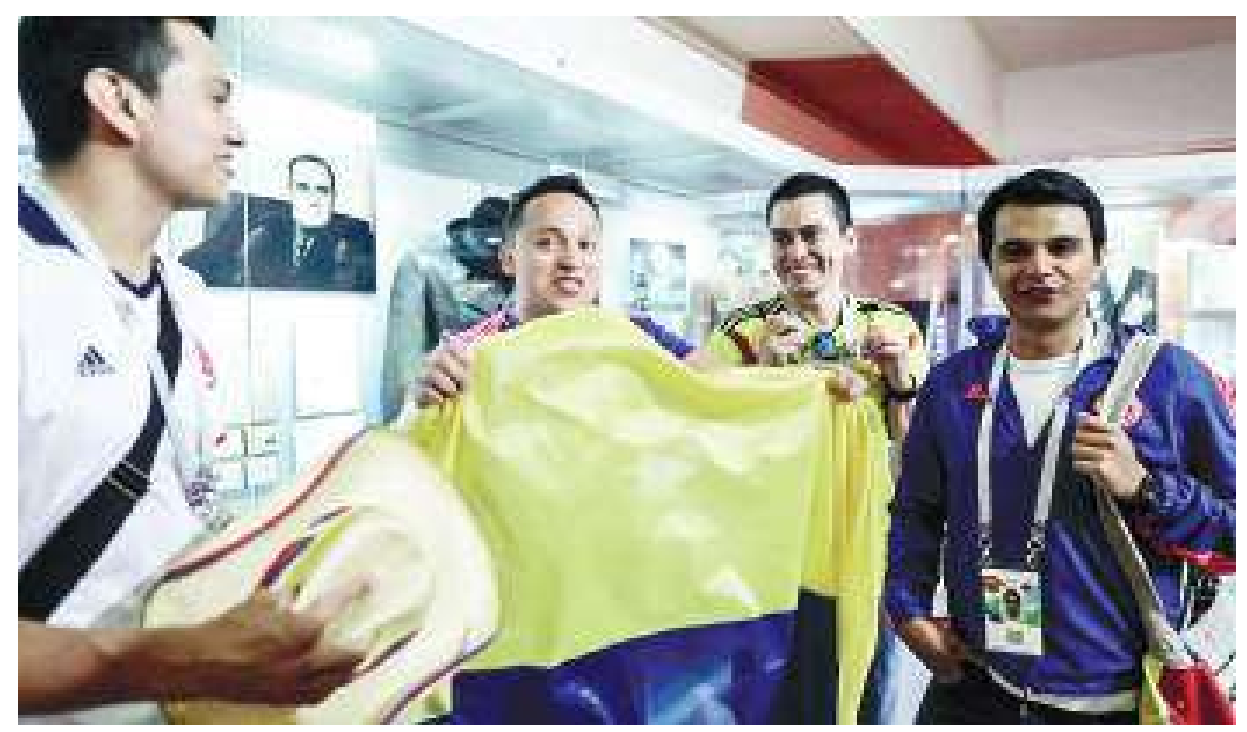

Колумбийские болельщики
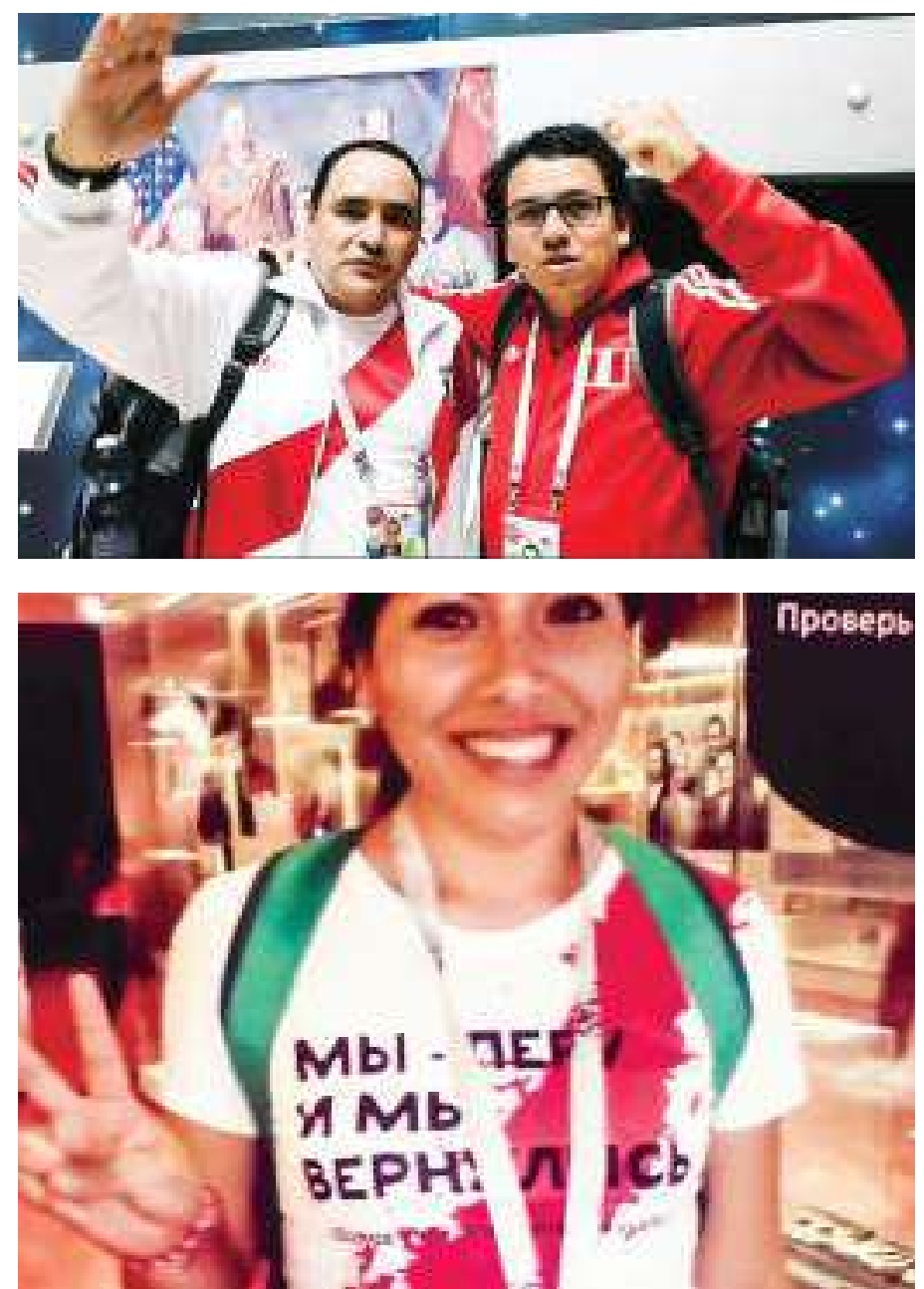

() Фалилеев М.Н., 2018

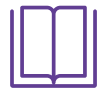

\section{История статьи:}

Поступила в редакцию: 23.07.2018

Принята к публикации: 02.08.2018

Модератор: Дмитрюк С. В.

Конфликт интересов: отсутствует

\section{Для цитирования:}

Фалилеев М.Н. Футбольный рекорд Музея космонавтики // Воздушно-космическая сфера. 2018. №3(96). С. 110-115.

\section{Болельщики сборной Перу}

